\title{
PENGARUH PENATAUSAHAAN BARANG MILIK NEGARA DAN PENERAPAN SISTEM INFORMASI MANAJEMEN AKUNTANSI BARANG MILIK NEGARA TERHADAP KUALITAS LAPORAN KEUANGAN
}

\author{
Tri Handayani Amaliah \\ Universitas Negeri Gorontalo \\ tri.handayani.amaliah@gmail.com \\ Siti Pratiwi Husain \\ Universitas Negeri Gorontalo \\ pratiwihusain04@gmail.com \\ Ni Wayan Selvianti \\ Universitas Negeri Gorontalo \\ niwayanselviyanti@gmail.com
}

\begin{abstract}
ABSTRAK
Tujuan dari penelitian ini untuk mengetahui: 1) besarnya pengaruh penatausahaan barang milik Negara terhadap kualitas laporan keuangan, 2) besarnya pengaruh penerapan Sistem Informasi Manajemen Akuntansi Barang Milik Negara Terhadap Kualitas Laporan Keuangan, dan 3) besarnya pengaruh besarnya pengaruh penatausahaan barang milik Negara dan penerapan Sistem Informasi Manajemen Akuntansi Barang Milik Negara Terhadap Kualitas Laporan Keuangan. Penelitian ini dilakukan dengan menggunakan data primer yang dikumpulkan dari beberapa pembagian kuesioner. Sampel dalam penelitian ini berjumlah 50 Responden. Data analisis dengan menggunakan analisis regresi linier berganda dengan menggunakan software SPSS 16 untuk mengolah data. Hasil penelitian ini menunjukkan bahwa penatausahaan barang milik negara tidak berpengaruh signifikan terhadap kualitas laporan keuangan sedangkan, penerapan sistem informasi manajemen akuntansi barang milik negara berpengaruh signifikan terhadap kualitas laporan keuangan. Serta secara simultan penatausahaan barang milik negara dan penerapan sistem informasi manajemen akuntansi barang milik negara berpengaruh signifikan terhadap kualitas laporan keuangan.
\end{abstract}

Kata Kunci: Penatausahaan, Sistem Informasi Manajemen Akuntansi Barang Milik Negara, Laporan Keuangan

\section{Pendahuluan}

Laporan keuangan merupakan media bagi seluruh entitas dalam hal ini pemerintah untuk mempertanggungjawabkan kinerja keuangannya kepada publik. Pemerintah harus mampu menyajikan laporan keuangan yang mengandung informasi keuangan yang berkualitas (Anggraeni. 2015). Dalam standar akuntansi pemerintahan (SAP) dijelaskan bahwa laporan keuangan berkualitas itu memenihi karakteristik: relevan, Andal, Dapat dibandingkan dan Dapat dipahami (PP No. 71 Tahun 2010).

Kualitas laporan keuangan pemerintah pusat yang lebih baik dari periode sebelumnya, ditandai dengan berubahnya opini yang diberikan Badan Pemeriksa Keuangan (BPK) atas LKPP misal, dari opini tidak memberikan pendapat menjadi Wajar Dengan Pengecualian (WDP), atau dari WDP menjadi Wajar Tanpa Pengecualian (WTP). Salah satu cara untuk mewujudkan opini WTP adalah dengan mengelola barang milik negara (BMN) dengan benar. Pengelolaan BMN erat kaitannya dengan laporan keuangan karena dalam laporan keuangan disajikan juga laporan BMN (Novira, dkk.2017). 
Agar pelaporan di dalam neraca dapat diandalkan Penatausahaan Barang Milik Negara (BMN) sangat penting dilakukan. Sebagaimana yang tertuang dalam Peraturan Pemerintah Nomor 6 Tahun 2006 menyangkut Penatausahaan Barang Milik Negara (BMN) meliputi Pembukuan, Inventarisasiasi dan Pelaporan Barang Milik Negara, sesuai dengan ketentuan yang berlaku. Penatausahaan Barang Milik Negara bertujuan untuk mewujudkan tertib administrasi dan mendukung tertib pengelolaan barang milik Negara. Hasil Penatausahaan Barang Milik Negara ini nantinya dapat digunakan dalam rangka (a) penyusunan necara pemerintah pusat setiap tahun, (b) perencanaan kebutuhan pengadaan dan pemeliharaan barang milik Negara setiap tahun untuk digunakan sebagai bahan penyusunan rencana anggaran, dan (c) pengamanan administrasi barang milik Negara (Banta 2014).

Dalam penerapan sistem informasi manajemen akuntansi barang milik Negara (SIMAK BMN) pada Kantor Wilayah Kementrian Agama Provinsi Gorontalo masih belum maksimal dimana dalam pencatatan pada aplikasi SIMAK belum sesuai dengan prinsip yang seharusnya dijalankan, dimana data yang ada dalam SIMAK BMN tidak update dengan penanggungjawab keuangan dimasing-masing Sub Bag/Bagian/Bidang, perekaman barang yang ada di daftar barang keuangan tidak update di SIMAK BMN, selain itu banyak barang rusak seperti peralatan dan mesin yang belum diusulkan penghapusan, sehingga menyebabkan data BMN real tidak sesuai dengan laporan.

Penerapan SIMAK BMN dapat mempengaruhi kualitas laporan keuangan di lihat dari hasil penelitian (Nasrudin 2015) yang mengatakan bahwa penerapan sistem informasi manajemen akuntansi barang milik Negara dapat menghasilkan kualitas informasi BMN yang digunakan oleh suatu entitas akuntansi barang, sehingga dapat mempengaruhi kualitas laporan keuangan yang dihasilkan, hal ini terbukti dengan adanya kemajuan opini yang diberikan terhadap Laporan Keuangan Kementerian/Lembaga oleh Badan Pemeriksa Keuangan. Status Opini WTP semakin banyak diraih oleh kementerian/lembaga, yang secara langsung merupakan peran dari SIMAK-BMN dalam menyajikan laporan barang milik negara.

Berdasarkan uraian latar belakang maka yang menjadi tujuan penelitian adalah untuk menganalisis pengaruh penatausahaan Barang Milik Negara dan penerapan sistem informasi manajemen akuntansi barang milik Negara (SIMAK BMN) terhadap kualitas laporan keuangan pada Kantor Wilayah Kementrian Agama Provinsi Gorontalo. 
Pengaruh Penatausahaan Barang Milik Negara Dan Penerapan Sistem Informasi Manajemen Akuntansi Barang Milik Negara Terhadap Kualitas Laporan Keuangan

\section{Kerangka Teori}

Menurut Peraturan Pemerintah Nomor 71 Tahun 2010 untuk mewujudkan laporan keuangan yang berkualitas, laporan keuangan harus memenuhi karakteristik kualitatif yang diartikan sebagai ukuran -ukuran normatif yang perlu diwujudkan dalam informasi akuntansi sehingga dapat memenui tujuannya. Empat prasyarat normatif yang diperlukan agar laporan keuangan dapat memenuhi kualitas yang diinginkan, yaitu : (i) relevan, yaitu memiliki manfaat umpan balik, manfaat prediktif, tepat waktu, dan lenglap; (ii) andal, yaitu penyajiannya jujur, dapat diverifikasi, dan netralitas; (iii) dapat dibandingkandengan laporan keuangan periode sebelumnya dan/atau entitas yang menerapkan kebijakan akuntansi yang sama; dan (iv) dapat dipahami, informasi yang disajikan dan istilah yang digunakan dapat dipahami oleh pengguna.

Menurut Peraturan Menteri Keuangan Nomor 120/PMK.06/2007 tentang Penatausahaan BMN, Penatausahaan BMN adalah rangkaian kegiatan yang meliputi pembukuan, inventarisasiasi dan pelaporan BMN sesuai ketentuan yang berlaku. Pembukuan BMN adalah kegiatan pendaftaran dan pencatatan BMN ke dalam daftar barang menurut penggolongan dan kodefikasi. Inventarisasiasi BMN adalah kegiatan pendataan, pencatatan dan pelaporan hasil pendataan BMN. Pelaporan adalah kegiatan penyampaian data dan informasi yang dilakukan oleh unit pelaksana penatausahaan BMN pada pengguna barang dan pengelola barang. Maksud dari pelaporan adalah agar semua data dan informasi mengenai BMN dapat disajikan dan disampaikan kepada pihak yang berkepentingan dengan akurat guna mendukung pelaksanaan pengambilan keputusan dalam rangka pengelolaan BMN dan sebagai bahan penyusunan Neraca Pemerintah Pusat.

Sistem Informasi Manajemen Akuntansi Barang Milik Negara (SIMAK-BMN) merupakan sistem terpadu yang merupakan gabungan prosedur manual dan komputerisasi dalam rangka menghasilkan data transaksi untuk mendukung penyusunan neraca. Dan pelaksanaan akuntansi BMN dibantu dengan perangkat lunak (software) SIMAK-BMN yang memungkinkan penyederhanaan dalam proses manual dan mengurangi tingkat kesalahan manusia (human error) dalam pelaksanaannya. Aplikasi SIMAK BMN merupakan salah satu cara untuk mengetahui dan meninjau sejauh mana sistem informasi yang sedang berjalan telah mampu memenuhi kebutuhan organisasi, hal ini dapat dilihat dari segi teknis, operasional, dan ekonomis khususnya dalam lingkup kegiatan pengelolaan aset organisasi, serta dapat meminimalisir resiko pada saat ini dan dikemudian hari (Fithiyah, 2018). Berdasarkan 
lampiran Peraturan Menteri Keuangan Nomor 171/PMK.05/2007 sebagaimana yang telah di rubah menjadi PMK No. 233/PMK.05/2007 tentang Sistem Akuntansi dan Pelaporan Keuangan Pemerintah Pusat pada bagian keempat menyebutkan bahwa Sistem Informasi Manajemen dan Akuntansi Barang Milik Negara (SIMAK-BMN) memiliki 6 prinsip yaitu (1) Ketaatan, (2) Konsistensi, (3) Kemampubandingan, (4) Materialitas, (5) Obyektif, (6) Kelengkapan.

$\mathrm{H}_{1} \quad$ : Terdapat pengaruh penatausahaan Barang Milik Negara (BMN) terhadap kualitas laporan kaungan

$\mathrm{H}_{2}$ : Terdapat pengaruh Sistem Informasi Manajemen Akuntansi Barang Milik Negara (SIMAK BMN) terhadap kualitas laporan kaungan

$\mathrm{H}_{3} \quad$ : Terdapat pengaruh penatausahaan Brang Milik Negara (BMN) dan Sistem Informasi Manajemen Akuntansi Barang Milik Negara (SIMAK BMN) terhadap kualitas laporan kaungan

\section{Metode}

Dalam penelitian ini peneliti berusaha menggambarkan tentang bagaimana penatausahaan barang milik negara dan penerapan Sistem Informasi Manajemen Akuntansi Barang Milik Negara (SIMAK BMN) dapat mempengaruhi kualitas laporan keuangan. Dalam penelitian ini terdapat 2 variabel bebas yaitu Penatausahaan BMN $\left(\mathrm{X}_{1}\right)$ dan Penerapan Sistem Informasi Manajemen Akuntansi Barang Milik Negara (SIMAK BMN) $\left(\mathrm{X}_{2}\right)$, serta Kualitas laporan keuangan (Y).

Populasi dalam penelitian ini adalah seluruh pegawai pada Kantor Wilayah Kementrian Agama Provinsi Gorontalo yang berjumlah 117 orang. Dalam penelitian ini menggunakan teknik probability sampling. Probability sampling adalah teknik pengambilan sampel yang memberikan peluang yang sama bagi setiap unsur (anggota) populasi untuk dipilih menjadi anggota sampel. Sampel dalam penelitian ini berjumlah 50 0rang.

Teknik pengumpulan data dalam penelitian ini menggunakan kuesioner (Angket). Kuesioner merupakan teknik pengumpulan data yang dilakukan dengan cara memberi seperangkat pertayaan atau pernyataan tertulis kepada responden untuk dijawabnya. Kuesioner merupakan teknik pengumpulan data yang efisien bila peneliti tahu dengan pasti variable yang akan diukur dan tahu apa yang bisa diharapkan dari responden (Sugiyono, 2017). Sementara itu teknik analisis data yang akan digunakan dalam penelitian ini terdiri atas 
statistic deskriptif, uji asumsi klasik, serta uji hipotesis menggunakan model analisis regresi berganda dengan menggunakan uji interaksi yang tersiri atas uji koefisien determinasi, uji t, dan uji F.

\section{Hasil dan Pembahasan}

\section{Hasil uji signifikansi parsial (Uji t)}

Hasil pengujian secara parsial (uji t) antara variabel penatausahaan barang milik Negara dan sistem informasi manajemen akuntansi barang milik Negara terhadap kualitas laporan keuangan dapat dilihat dalam tabel di bawah ini.

\section{Tabel 1. Hasil Uji Signifikansi (uji-t)}

Coefficients $^{\mathrm{a}}$

\begin{tabular}{|c|c|c|c|c|c|c|}
\hline \multirow{2}{*}{\multicolumn{2}{|c|}{ Model }} & \multicolumn{2}{|c|}{$\begin{array}{c}\text { Unstandardized } \\
\text { Coefficients } \\
\end{array}$} & \multirow{2}{*}{\begin{tabular}{|c|}
$\begin{array}{c}\text { Standardized } \\
\text { Coefficients }\end{array}$ \\
Beta \\
\end{tabular}} & \multirow[b]{2}{*}{$\mathrm{t}$} & \multirow[b]{2}{*}{ Sig. } \\
\hline & & B & $\begin{array}{l}\text { Std. } \\
\text { Error }\end{array}$ & & & \\
\hline \multirow[t]{3}{*}{1} & (Constant) & 18.494 & 5.969 & & 3.098 & .003 \\
\hline & $\begin{array}{l}\text { Penatausahaan_Barang_M } \\
\text { ilik_Negara }\end{array}$ & .081 & .137 & .082 & .589 & .559 \\
\hline & $\begin{array}{l}\text { Sistem_Informasi_Manaje } \\
\text { men_Akuntansi_Barang_ } \\
\text { Milik_Negara }\end{array}$ & .366 & .145 & .349 & 2.512 & .015 \\
\hline
\end{tabular}

a. Dependent Variabel:

Kualitas_laporan_Keuangan

Sumber: Hasil olahan data SPSS 16, 2019

Hasil Uji-t variabel penatausahaan barang milik Negara (X1) terhadap Kualitas Laporan Keuangan (Y) diperoleh nilai $t_{\text {hitung }}$ sebesar 0,589 yang berarti lebih kecil dari $t_{\text {tabel }}$ yaitu 1,67793, dengan nilai probabilitas (p) 0,559 yaitu lebih besar dari 0,05. Maka dengan demikian untuk hipotesis pertama ditolak yaitu $\mathrm{h} 0$ diterima dan $\mathrm{h}_{\mathrm{a}}$ ditolak yang berarti penatausahaan barang milik daerah tidak berpengaruh signifikan terhadap kualitas laporan keuangan. Sedangkan Penerapan Sistem Informasi Manajemen Akuntansi Barang Milik Negara (SIMAK BMN) (X2) terhadap kualitas laporan keuangan diperoleh nilai $t_{\text {hitung }}$ sebesar 2.512, dan nilai $t_{\text {tabel }}$ adalah sebesar 1,67793, maka dalam hal ini diperoleh hasil $t_{\text {hitung }}>t_{\text {tabel }}$ dengan Probabilitas (p) 0,015 yaitu lebih kecil dari 0,05.berdasarkan hasil tersebut, maka H0 di tolak dan Ha diterima yang berarti Penerapan Sistem Informasi Manajemen Akuntansi 
Barang Milik Negara (SIMAK BMN) berpengaruh signifikan terhadap kualitas laporan keuangan.

\section{Hasil Uji Signifikansi Simultan (Uji-F)}

Hasil pengujian secara simultan (uji f) antara variabel penatausahaan barang milik Negara dan sistem informasi manajemen akuntansi barang milik Negara terhadap kualitas laporan keuangan dapat dilihat dalam tabel di bawah ini.

Tabel 1. Hasil Uji Signifikansi (Uji F)

ANOVA $^{\text {b }}$

\begin{tabular}{|ll|r|r|r|r|r|}
\hline \multicolumn{2}{|l|}{ Model } & \multicolumn{1}{|c|}{$\begin{array}{c}\text { Sum of } \\
\text { Squares }\end{array}$} & df & Mean Square & F & \multicolumn{1}{c|}{ Sig. } \\
\hline 1 & Regression & 391.109 & 2 & 195.555 & 3.907 & $.027^{\mathrm{a}}$ \\
& Residual & 2352.452 & 47 & 50.052 & & \\
& Total & 2743.562 & 49 & & & \\
\hline
\end{tabular}

a. Predictors: (Constant),

Sistem_Informasi_Manajemen_Akuntansi_Barang_Milik_Negara,

Penatausahaan_Barang_Milik_Negara

b. Dependent Variabel: Kualitas_laporan_Keuangan

Sumber : Hasil olahan data SPSS 16, 2019

Berdasarkan hasil pengujian dengan menggunakan uji-F pada tabel Maka dapat diketahui $F_{\text {hitung }}$ sebesar 3.907 dan nilai $F_{\text {tabel }}$ sebesar 3,20. Sedangkan nilai signifikansinya sebesar 0,027. Maka dapat disimpulkan $F_{\text {hitung }}>F_{\text {tabel }}$ dengan tingkat signifikansi lebih kecil dari 0,05, sehingga dapat dikatakan bahwa penatausahaan Barang Milik Negara (X1) dan penerapan Sistem Informasi Manajemen Akuntansi Barang Milik Negara (SIMAK BMN) (X2) secara simultan memiliki pengaruh yang signifikan terhadap kualitas laporan keuangan (Y). dengan demikian maka h0 ditolak dan ha diterima.

\section{Uji Koefisien Determinasi $\left(R^{2}\right)$}

Uji koefisien determinasi R2 dilakukan untuk mengukur seberapa jauh kemampuan model dalam menerangkan variasi variabel dependen. Adapun hasil uji koefisien determinasi dapat dilihat pada tabel berikut: 
Tabel 3

Hasil Pengujian Koefisien Determinasi

Model Summary

\begin{tabular}{|l|r|r|r|r|}
\hline Model & R & R Square & $\begin{array}{c}\text { Adjusted R } \\
\text { Square }\end{array}$ & $\begin{array}{l}\text { Std. Error of } \\
\text { the Estimate }\end{array}$ \\
\hline 1 & $.378^{\mathrm{a}}$ & .143 & .106 & 7.07476 \\
\hline
\end{tabular}

Berdasarkan hasil pengujian statistik menunjukkan variabel penatausahaan barang milik Negara (X1) dan Penerapan Sistem Informasi Manajemen Akuntansi Barang Milik Negara (SIMAK BMN) (X2) mampu menjelaskan tentang kualitas laporan keuangan (Y) sebesar 0,106 atau 10,6\%. Sedangkan sisanya sebesar 89,4 \% tentang kualitas laporan keuangan dapat dijelaskan oleh variabel lain yang tidak terdapat dalam penelitian ini.

\section{Pengaruh Penatausahaan Barang Milik Negara terhadap Kualitas Laporan Keuangan}

Hasil analisis yang telah dilakukan menunjukkan bahwa penatausahaan barang milik Negara tidak berpengaruh signifikan terhadap kualitas laporan keuangan. Hal ini didasarkan pada pada hasil pengujian statistik yang menghasilkan $t_{\text {hitung }}$ sebesar 0,589 dan nilai $t_{\text {tabel }}$ sebesar 1,67793 atau nilai $t_{\text {hitung }}$ lebih kecil dari $t_{\text {tabel }}$ dengan nilai signifikansi 0,559 atau lebih besar dari 0,05. Sehingga H0 diterima dan Ha ditolak.

Berdasarkan hasil analisis jawaban responden atas pernyataan-pernyataan pada variabel penatausahaan barang milik Negara pada Kantor Wilayah Kementrian Agama ada tiga indikator yaitu: Pembukuan, Inventarisasi, dan Pelaporan, ditemukan bahwa variabel penatausahaan berada pada kriteria sangat baik dengan persentase sebesar 91,66\%. Hasil pengujian koefisien determinasi secara parsial menunjukkan variabel penatausahaan barang milik negara memiliki nilai pengaruh sebesar 0,7\%. Variabel penatausahaan Barang Milik Negara tidak berpengaruh secara maksimal atau 100\% karena masih ada permasalahan yang terjadi dilapangan.

Permasalahan yang terjadi dilapangan terkait dengan penatausahaan barang milik Negara yaitu masih banyak ditemukan barang yang kondisinya rusak berat namun tercatat berkondisi baik, asset yang tidak mempunyai nomor identitas, BMN yang secara fisik ada namun belum tercatat hal ini menyebabkan data BMN real tidak sesuai dengan laporan. Permasalahan mengenai penatausahaan BMN juga dapat dilihat dari hasil jawaban responden dimana pada indikator inventarisasi masih ada beberapa responden yang memberikan jawaban 
dengan skor 3, ini menandakan bahwa dalam inventarisasi barang milik Negara masih belum maksimal. Sehingga dapat disimpulkan bahwa penatausahaan barang milik Negara tidak berpengaruh signifikan terhadap kualitas laporan keuangan pemerintah daerah karena masih lemahnya penatausahaan barang milik Negara di Kantor Wilayah Kementrian Agama Provinsi Gorontalo yang belum dilaksanakan sesuai dengan permendagri No. 17 Tahun 2007 dan PP No. 27 tahun 2014 tentang pedoman teknis pengelolaan barang milik Negara/daerah. Oleh karena itu Kantor Wilayah Kementrian Agama Provinsi Gorontalo perlu memperhatikan kembali penerapan Permendagri No. 17 tahun 2014 tentang pedoman teknis pengelolaan Barang Milik Negara/Daerah.

Hasil penelitian ini tidak mendukung hipotesis pertama yang telah dirumuskan bahwa penatausahan barang milik Negara memiliki pengaruh signifikan terhadap kualitas laporan keuangan. Hasil penelitian ini sesuai dengan hasil penelitian (Banta 2014) yaitu tidak terdapat pengaruh signifikan parsial penatausahaan barang milik Negara terhadap kualitas laporan keuangan. Hasil ini berbeda dengan penelitian (Anggraeni. 2015) dimana hasilnya menunjukkan bahwa penatausahaan barang milik Negara/Daerah berpengaruh signifikan terhadap kualitas laporan keuangan. Hasil penelitian ini berbeda karena penelitian ini dilakukan di tempat yang berbeda dan peneliti yang berbeda.

\section{Pengaruh Penerapan Sistem Informasi Manajemen Akuntansi Barang Milik Negara (SIMAK BMN) terhadap Kualitas Laporan Keuangan}

Hasil analisis yang telah dilakukan menunjukan bahwa terdapat pengaruh signifikan dari Penerapan Sistem Informasi Manajemen Akuntansi Barang Milik Negara (SIMAK BMN) terhadap kualitas laporan keuangan. Hal ini didasarkan pada hasil pengujian statistik yang memberikan $t_{\text {hitung }}$ untuk variabel Penerapan Sistem Informasi Manajemen Akuntansi Barang Milik Negara (SIMAK BMN) sebesar 2.512,dengan nilai $t_{\text {tabel }}$ adalah sebesar 1,6793 atau $t_{\text {hitung }}>t_{\text {tabe }}$ dengan nilai signifikansi sebesar 0,015 atau lebih kecil dari 0,05. Sehingga h0 ditolak dan Ha diterima.

Berdasarkan hasil analisis jawaban responden atas pernyataan-pernyataan pada variabel penerapan Sistem Informasi Manajemen Akuntansi Barang Milik Negara (SIMAK BMN) pada Kantor Wilayah Kementrian Agama Provinsi Gorontalo yang terdiri atas 6 (Enam) indikator yaitu Ketaatan, Konsistensi, Kemampubandingan, Materialitas, Obyektif, dan Kelengkapan. Berdasarkan analisis deskriptif yang telah dilakukan diketahui bahwa 
variabel Penerapan Sistem Informasi Manajemen Akuntansi Barang Milik Negara (SIMAK BMN) berada pada kriteria sangat baik dengan persentase sebesar 86,87\%.

Hasil pengujian Koefisien determinasi secara parsial menunjukkan variabel penerapan Sistem Informasi Manajemen Akuntansi Barang Milik Negara (SIMAK BMN), memiliki pengaruh parsial terhadap kualitas laporan keuangan yaitu sebesar 11,8\%. Variabel Penerapan Sistem Informasi manajemen Akuntansi Barang Milik Negara belum berpengaruh secara maksimal atau 100\% karena masih ada permasalahan yang terjadi dilapangan.

Permasalahan yang terjadi dilapangan yaitu terkait dengan Penerapan Sistem Informasi Manajemen Akuntansi Barang Milik Negara (SIMAK BMN) yaitu data yang ada dalam SIMAK BMN tidak update dengan penanggungjawab keuangan dimasing-masing Sub Bag/Bagian/Bidang, perekaman barang yang ada di daftar barang keuangan tidak update di SIMAK BMN, selain itu banyak barang rusak seperti peralatan dan mesin yang belum diusulkan penghapusan, sehingga menyebabkan data BMN real tidak sesuai dengan laporan.

Penerapan Sistem Informasi Manajemen Akuntansi Barang Milik Negara pada Kantor Wilayah Kementrian Agama Propinsi Gorontalo berada pada kategori sangat baik, walaupun demikian dari kuesioner yang telah disebar dapat diketahui masih ada beberapa reponden yang memberikan jawaban dengan skor 3 pada indikator ketaatan, materialitas dan objektif, beberapa pernyataan dengan skor ter rendah yaitu: (1) Pengguna SIMAK BMN disetiap bagian/bidang memperbaharui data simak secara berkala, (2) Pengguna Sistem Informasi Manajemen Akuntansi Barang Milik Negara (SIMAK BMN) (SIMAK BMN) memberikan informasi tepat waktu kepada Kuasa Pengguna Barang, (3) Pengguna SIMAK BMN membuat laporan pada SIMAK BMN sesuai dengan Keadaan Yang sebenarnya. Hal Ini menandakan bahwa dalam penerapan SIMAK BMN pada Kantor Wilayah Kementrian Agama Provinsi Gorontalo belum taat dalam penggunaannya serta belum menjalankan prinsip materialitas dan objektif dalam penggunaan SIMAK BMN secara maksimal atau dapat disimpulkan bahwa penerapan sistem informasi manajemen akuntansi barang milik Negara pada Kantor Wilayah Kementrian Agama belum dilaksanakan sesuai dengan prinsip yang telah ditentukan. Sehingga para pegawai BMN Kantor Wilayah Kementrian Agama harus lebih memperhatikan hal tersebut sesuai dengan PMK No. 233/PMK.05/2007 tentang Sistem Akuntansi dan Pelaporan Keuangan Pemerintah Pusat. 
Pengaruh Penatausahaan Barang Milik Negara dan Penerapan Sistem Informasi Manajemen Akuntansi Barang Milik Negara (SIMAK BMN) terhadap Kualitas Laporan

\section{Keuangan}

Berdasarkan hasil analisis yang telah dilakukan, diperoleh hasil yang menunjukkan bahwa Penatausahaan barang milik Negara dan penerapan Sistem Informasi Manajemen Akuntansi Barang Milik Negara (SIMAK BMN) secara bersama-sama (Simultan) memiliki pengaruh yang signifikan terhadap kualitas laporan keuangan. Hal ini didasarkan pada hasil pengujian statistik yang memperoleh nilai Fhitung sebesar 3.907 dan nilai $\mathrm{F}_{\text {tabel }}$ sebesar 3,20. Sedangkan nilai signifikansinya sebesar 0,027. Maka dapat disimpulkan $F_{\text {hitung }}>F_{\text {tabel }}$ dengan tingkat signifikansi lebih kecil dari 0,05, sehingga h0 ditolak dan ha diterima.

Berdasarkan hasil dari pengujian statistik diperoleh koefisien determinasi $\mathrm{R}^{2}$ sebesar 0,106 atau 10,6\%. Sedangkan sisanya sebesar 89,4\% tentang kualitas laporan keuangan dapat dijelaskan oleh variabel lain yang tidak terdapat dalam penelitian ini. Agar dapat memenuhi laporan keuangan yang berkualitas kantor wilayah kementrian agama provinsi Gorontalo harus serius menyikapi permasalahan yang terjadi dilapangan.

Hasil penelitian ini didukung oleh hasil penelitian (Novira, 2017) berdasarkan pengujian hipotesiis simultan diketahi penatausahaan barang milik Negara dan Penerapan SIMAK BMN berpengaruh signifikan terhadap kualitas laporan keuangan.

\section{Simpulan}

Berdasarkan hasil penelitian dan pembahasan diatas, maka dapat ditarik kesimpulan sebagai berikut:

1. Hasil pengujian hipotesis pertama menunjukkan bahwa Penatausahaan Barang Milik Negara tidak berpengaruh signifikan terhadap kualitas laporan keuangan, berdasarkan hasil analisis reponden diketahui penatausahaan barang milik Negara pada kantor wilayah kementrian agama berada pada kategori sangat baik, namun masih ada variabel yang dapat lebih meningkatkan kualitas laporan keuangan yang tidak diteliti pada penelitian ini.

2. Hasil pengujian hipotesis kedua menunjukkan bahwa Penerapan sistem Informasi Manajemen Akuntansi Barang Milik Negara berpengaruh signifikan terhadap kualitas laporan keuangan. Hal ini dapat diketahui Berdasarkan uji statistik variabel yang dilakukan. 
Pengaruh Penatausahaan Barang Milik Negara Dan Penerapan Sistem Informasi Manajemen Akuntansi Barang Milik Negara Terhadap Kualitas Laporan Keuangan

3. Hasil pengujian hipotesis ketiga menunjukkan bahwa variabel Penatausahaan Barang Milik Negara dan Penerapan Sistem Informasi Manajemen Akuntansi Barang Milik Negara secara bersama-sama (simultan) berpengaruh signifikan terhadap kualitas laporan keuangan dengan Koefisien determinasi $\left(\mathrm{R}^{2}\right)$ dari model penelitian ini adalah sebesar 0,106 (10,6\%). Dengan demikian variabel Penatausahaan Barang Milik Negara dan Penerapan Sistem Informasi Manajemen Akuntansi Barang Milik Negara dapat mempengaruhi variabel kualitas laporan keuangan sebesar 10,6\%, Sedangkan sisanya sebesar 89,4 \% tentang kualitas laporan keuangan dapat dijelaskan oleh variabel lain yang tidak terdapat dalam penelitian ini.

\section{Reference}

Banta, Z.M. (2014). Analisis Penatausahaan Barang Milik Negara Guna Meningkatkan Kualitas Laporan Keuangan Pemerintah (Studi Pada Kantor Kementrian Agama Kota Sabang Aceh). 4(1).

Ghina, G. (2018). Peranan Sistem Informasi Manajemen Akuntansi Barang Milik Negara (Simak Bmn) Dan Aplikas1 Persediaan Dalam Penyusunan Laporan Keuangan Pada Kantor Pertanahan Kabupaten Sukabumi. Thesis: Universitas Muhammadiyah Sukabumi.

Martikawati, G., Jantje, T., \& Rudy, P. (2018). Analisis Penatausahaan Barang Milik Negara Melalui Penggunaan Aplikasi SIMAK BMN Pada Kantor Kementrian Agama Kabupaten Minahasa. 13(3): 216-24.

Nasrudin, E. (2015). Efektivitas Sistem Informasi Manajemen Dan Akuntansi Barang Milik Negara (SIMAK BMN) Terhadap Pengelolaan Aset Negara. Jurnal Akuntansi Universitas Jember. 13(2): 45-56.

Norhina, K., Mokhamad, A., \& Layinaturrobaniyah. (2018). Administration and Optimization of Fixed Assets at the Secretariat of Election Commission for West Java Province, Indonesia. International Journal of Economics, Commerce and Management VI(3): 18599.www.ebscohost.com.

Novira, J., Dini, W.H., \& Muhamad, M. (2017). Pengaruh Penatausahaan Dan Penerapan Sistem Informasi Manajemen Akuntansi Barang Milik Negara (SIMAK BMN) Terhadap Kualitas Laporan Keuangan (Studi Pada Kantor Pusat Dan Kantor Wilayah Direktorat Jenderal Kekayaan Negara DKI Jakarta). Periode 2017. 4(3): 2796-2803.

Pamungkas, B. (2011). Evaluasi Aplikasi Sistem Informasi Manajemen Akuntansi Barang Milik Negara (SIMAK BMN) Kaitannya Dalam Pencatatan Nilai Aset Tetap Pemerintah Studi Kasus pada Pusat Penelitian dan Pengembangan Tanaman Pangan Bogor. Jurnal Ilmiah Ranggagading, Vol. 11 No. 2.

Peraturan Pemerintah RI Nomor 6 Tahun 2006 Tentang Pengelolaan Barang Milik Negara, Penerbit Kementerian Agama RI, Jakarta.

Peraturan Pemerintah RI Nomor 71 Tahun 2010 Tentang Standar Akuntansi Pemerintahan

Peraturan Menteri Keuangan R.I. Nomor 120/PMK.06/2007 tentang Penatausahaan Barang Milik Negara

Undang-undang R.I Nomor 1 tahun 2004 tentang Perbendaharaan Negara 
Pengaruh Penatausahaan Barang Milik Negara Dan Penerapan Sistem Informasi Manajemen Akuntansi Barang Milik Negara Terhadap Kualitas Laporan Keuangan

Undang-Undang Nomor 17 Tahun 2003 tentang Keuangan Negara

Narimawati, U. (2008). Metodologi Penelitian Kualitatif dan Kuantitatif Teori dan Aplikasi. Agung Media: Jakarta.

Nurlan, D. (2008). Akuntansi Keuangan daerah. Jakarta: Indeks. 2008.

Sugiyono. 2017. Metode Penelitian Kombinasi. Bandung: Alfa Beta. . 2015. Statistika Untuk Penelitian. Bandung: Alfa Beta. 